\title{
Academic Motivations of Pregrade Students in the Choice of International Business Career
}

\author{
Wagner Enoc Vicente-Ramos ${ }^{1}$, Brenda Gonzales Silva ${ }^{1}$, Shirley Teresa Nuñez Merino ${ }^{1}$, Silvana Marjorie Paucar \\ Lazo $^{1} \&$ Christian R. Mejia ${ }^{1}$ \\ ${ }^{1}$ Universidad Continental, Peru \\ Correspondence: Wagner Enoc Vicente-Ramos, Coordinador de Investigación de la Facultad de Ciencias de la \\ Empresa de la Universidad Continental, Universidad Continental, Peru
}

Received: December 14, 2019

Accepted: January 5, 2020

Online Published: January 7, 2020

doi:10.5430/ijhe.v9n2p85

URL: https://doi.org/10.5430/ijhe.v9n2p85

\begin{abstract}
The main objective of this research is to determine which is the most recurrent motivation by university students choose international business careers at 8 universities in Peru. The study sample is composed by 1242 international business students from the main universities in Peru. For this study, the Academic Motivation Scale (AMC) was used, this scale considers intrinsic motivation factors (knowledge, achievement, stimulating experiences), extrinsic motivation (identified regulation, introjected regulation, external introjected) and amotivation.

As a result, the research shows that the students wanted to achieve their goals (84\%), because it is aligned to their dreams $(83 \%)$, also that they want to show to other people that they are capable to generate business opportunities $(81 \%)$. On the other hand, the main demotivations were the fact that they don't care and just want to finish the career $(10 \%)$, they didn't know which career choose (13\%) and they didn't know the reason why they choose this career $(15 \%)$.

It is concludes that the factors of academic motivations (motivation, extrinsic motivations and intrinsic motivations) are positively related to the choice of the international business career. Where the most significant relationship is that between extrinsic motivation with external regulation and the choice of the international commercial career, to achieve its objectives such as giving a more positive image to family and friends. While the least significant relationship is that between the intrinsic motivation for stimulating experiences and the choice of an international business career.
\end{abstract}

Keywords: motivation, international business, universities, Peru

\section{Introduction}

Motivation is the complex union of psychological procedures that intervene in human behavior, this one can determine the path, meaning or vehemence of what is sought or unseen; taking as a target the satisfaction of the needs based on the emotions, thoughts, desires, aspirations, among others (Gonzales Serra, 2008). The motivation, etymologically, concerns what "moves" people to action. Theories of motivation more specifically focus on both what energizes and gives direction to behavitor. Throughout the history of experimental psychology various theories of motivation have thus attempted to predict learning, performance, and behavitor change (Ryan and Deci, 2017)

To understand how motivation works, scientists focus on the person's internal dispositions (motives) and sometimes on external events. The internal dispositions are classified as biological or psychological variables, while the external dispositions (the sources that attract the person) are labeled as environmental variables, that is, as incentives and goals (Deckers, 2018).

\subsection{Literature Review}

Ryan and Deci (2017) develop the theory of self-determination as an approach to motivation and human personality, based on three innate psychological needs: autonomy, with which one feels self-motivated when behaving; competence, which indicates the need for an individual to feel competent while engaged in activities; and relationship, the desire to maintain relationships with friends, family, etc. Based on the theory of self-determination, social contexts can improve the self-motivation of individuals by internalizing their external motivations and maintaining good behavior by satisfying their needs for autonomy and competence. 
Blašková, M., Majchrzak-Lepczyk, J., Hriníková, D. \& Blaško, R. (2019) consider that academic motivation represents the perceived and actively exploited strength and conviction of university members to pursue their academic responsibilities. Enthusiasm, self-discipline, perseverance, understanding, and positive energy are required to succeed in the appreciable achievement of academicians. In higher education, three basic kinds of academic motivation can be distinguished: motivation of teachers and scientists, motivation of administrative and managing staff and motivation of students.

Being our interest the motivation towards the development of student knowledge and personality dispositions and building a future career. It is the value a student places on learning a task or concept, and their personal interest in the concept, task, instructor, or school (Cayanus \& Martin, 2008). This means that to motivate is generally the process of instigating students to productive cognitive activities, actively learning the content of study (Patlins, 2017). Wilkesmann et al. (2012), on the basis of works by Ryan and Deci (2000) and Vallerand et al. (1992), distinguished three types of academic motivation, i.e., extrinsic, intrinsic, and amotivation.

Therefore, motivation is an important aspect during our lives, since, we take certain decisions supported by different motivations, being this an important aspect during the process of career choice. From the aforementioned surge the unknown of what are the most recurrent motivations by which students choose international business career in the main universities of Peru, since, this will allow to do an analysis of the reality. Additionally, it is necessary to emphasized that to the date no national investigations have been identified in this regard. The purpose of this study is to evaluate the level of motivation in international business students of the main universities of Peru.

\subsection{Research Model and Hypotheses}

Independent variables are based on the theory of self-determination (amotivation, extrinsic motivation and intrinsic motivation), which indicate the degree to which the motivations emanate from the self (that is, they are self-determined).

Amotivation (AM), is the state of lack of intention to act, where people do not act at all or act without intention. This state manifests itself, when they do not value an activity (Ryan, 1995), do not feel competent to do so (Bandura, 2002), or do not expect to produce a desired result.

Extrinsic motivation (EM), according to Woolfolk (2010) is valued by the results we will obtain externally and is divided into (EMir) extrinsic motivation of identified regulation, of (EMi) introjected and (EMer) external regulation.

Intrinsic motivation (IM) is the impulse that the human being has, pursuing personal interests with such conviction that it is gratifying for himself, since it is an internal impulse. The factors that determine intrinsic motivation are: (IMk) knowledge, (IMa) achievement and (IMse) stimulating experiences. (Woolfolk, 2010)

Satisfaction with the choice of international business career (SCIB) is considered as dependent variable.

From which the following conceptual model and hypotheses are established.

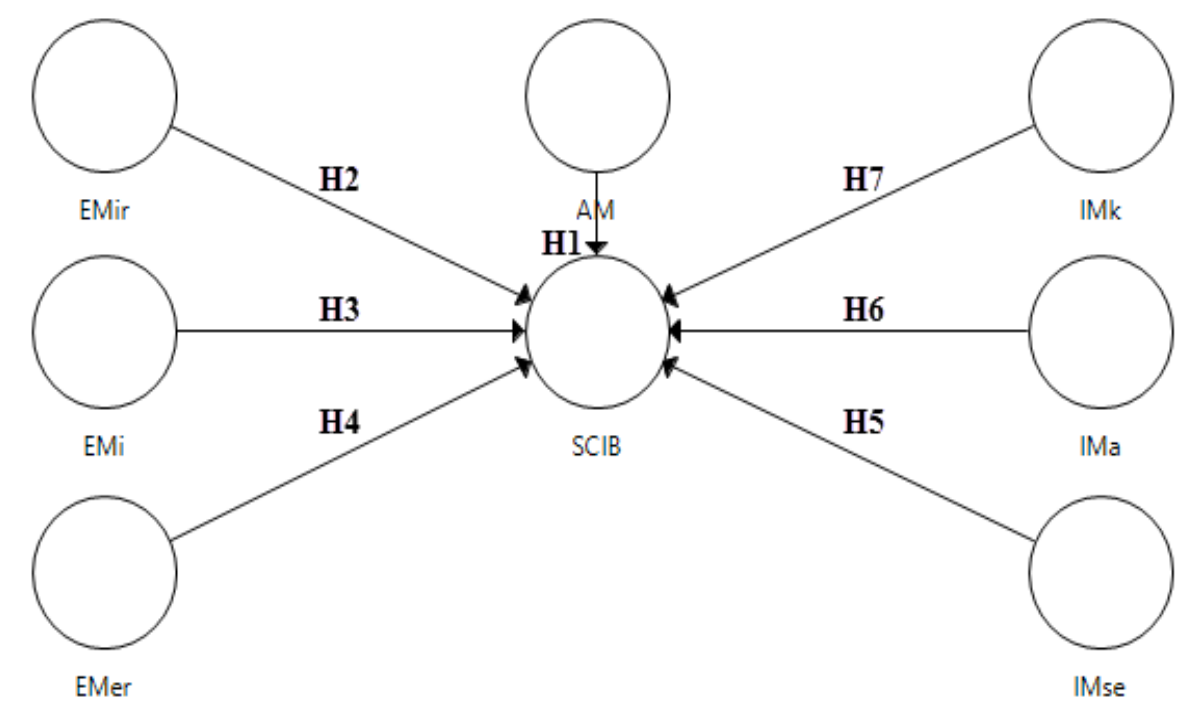

Figure 1. Conceptual model and hypotheses 
H1: There is a significant relationship between amotivation and choice of international business career.

$\mathrm{H} 2$ : There is a significant relationship between extrinsic motivation of identified regulation and choice of international business career.

H3: There is a significant relationship between extrinsic motivation introjected and choice of international business career.

H4: There is a significant relationship between extrinsic motivation with external regulation and choice of international business career.

H5: There is a significant relationship between intrinsic motivation to stimulating experiences and choice of international business career.

H6: There is a significant relationship between intrinsic motivation to achievement and choice of international business career.

H7: There is a significant relationship between intrinsic motivation to knowledge and choice of international business career.

\section{Method}

The method used in this research is cross-sectional descriptive descriptive, which is carried out in the period of time that begins in July and November of the year 2019.

It has been made an analytical cross-sectional study between July and November 2019.

\subsection{Population and Sample}

The study population consisted of 1234 students attending the 7 th to 10 th international business academic period of the following universities in Peru: University Mayor de San Marcos (Lima), Technological University of Peru (Lima), Continental University (Huancayo), Peruvian University of Applied Sciences (Lima), University of Lima (Lima), Scientific University of the South (Lima), Federico Villareal University (Lima) and Technological University of Peru (Lima). All identified students were considered as samples; non-random sampling was realized.

\subsection{Data Collection Instrument}

In this investigation, a targeted questionnaire was developed based on the "Academic Motivation Scale" of Deci and Ryan (1985) where the questions associated with each factor are determined as follows: AM (pgta_7, pgta_14, pgta_21 and pgta_28); EMir (pgta_3, pgta_10,pgta_17 and pgta_24); EMi (pgta_5,pgta_12, pgta_19 and pgta_26); EMer (pgta_2, pgta_9, pgta_16 and pgta_23); IMk (pgta_4, pgta_11, pgta_18 and pgta_25); IMa (pgta_6, pgta_13, pgta_20 and pgta_27); IMse (pgta_1, pgta_8, pgta_15 and pgta_22). In addition, information was taken from the book Woolfolk (2010) "Educational Psychology". From the first stage of data collection we obtained the main motivations for which the students choose international business career. For the validation of the instrument, the Delphi methodology was followed, by which the in-depth validation was carried out with 3 experts in International Business, Research and Psychology, the form was validated through the application of the questionnaire to 50 students, who participated simultaneously to the completion of the pilot questionnaire. After the first correction of the observations made by the experts, the instrument went through the second validation, in charge of 5 experts in Management, International Business, Research and Psychology. At these stages (for background and form validation) the evaluation of the questions was considered on a five-point scale (one was poor and five was very good), so at the end of this process each question reached an average score that was greater than or equal to seven points; these stages verified the comprehension of the questions, gaps were identified in the reagents, questions were eliminated and the data collection mechanism was refined. The instrument was statistically validated using Cronbach's Alpha for the intrinsic motivation factors (knowledge 0.821, achievement 0.803 , stimulating experiences 0.775 ), extrinsic motivation (identified regulation 0.734 , introjected regulation 0.829 , external introjected 0.861 ) and amotivation (0.720).

\section{Results}

\subsection{Descriptive Result}

Of 1243 interrogated students, $60.0 \%$ (744) were women, the median age was 21 years (interquartile range: 20-23 years), the universities with the most respondents were the Universidad Nacional Mayor de San Marcos (17.7\%), Universidad Nacional Federico Villarreal (16.2\%), Universidad Continental (16.1\%) and UTP (16.1\%). The median number of cycles he had already studied was 6 (interquartile range: 5-8 cycles) and the great majority only studied $(72.7 \%)$. 
Table 1. Characteristics of the student population surveyed in 8 Peruvian universities

\begin{tabular}{|c|c|c|}
\hline Variable & Frequency & Percentage \\
\hline \multicolumn{3}{|l|}{ Gender } \\
\hline Male & 496 & $40,0 \%$ \\
\hline Female & 744 & $60,0 \%$ \\
\hline \multicolumn{3}{|l|}{ Age } \\
\hline Mean and standard deviation & 21,9 & 2,4 \\
\hline Median and interquartile range & 21 & $20-23$ \\
\hline \multicolumn{3}{|l|}{ University } \\
\hline U. Continental & 200 & $16,1 \%$ \\
\hline U. Nac. Mayor de San Marcos & 220 & $17,7 \%$ \\
\hline U. Nac. Federico Villarreal & 201 & $16,2 \%$ \\
\hline UTP & 200 & $16,1 \%$ \\
\hline U. de Lima & 151 & $12,2 \%$ \\
\hline UPC & 101 & $8,2 \%$ \\
\hline IDAT & 87 & $7,0 \%$ \\
\hline UCSUR & 81 & $6,5 \%$ \\
\hline \multicolumn{3}{|l|}{ Academic period } \\
\hline Mean and standard deviation & 6,4 & 1,7 \\
\hline Median and interquartile range & 6 & $5-8$ \\
\hline \multicolumn{3}{|l|}{ Current situation } \\
\hline Student & 902 & $72,7 \%$ \\
\hline Student and worker & 339 & $27,3 \%$ \\
\hline
\end{tabular}

As for the most important motivations that the students had, we can see in Table 2 where a higher percentage was obtained with respect to the fact that they wanted to achieve their goals $(84.0 \%)$, due to the fact that it is aligned to their dreams (83.0\%), they want to demonstrate to others that they are capable to generate commercial opportunities $(80.9 \%)$. On the other hand, the main demotivations were the fact that they don't care and they just want to finish their careers $(10.1 \%)$, they didn't know what to choose (12.6\%) and that they didn't know why they chose that career $(15.3 \%)$. 
Table 2. Most important motivations to study international business career in students of 8 Peruvian universities

\begin{tabular}{|c|c|}
\hline Question & $\mathrm{N}(\%)$ \\
\hline Pgta_10 To reach mi goals & $1041(84,0 \%)$ \\
\hline Pgta_17 It is aligned to my dreams (travel, meet new cultures, learn new languages). & $1030(83,0 \%)$ \\
\hline Pgta_16 To show others that I am capable to generate business opportunities in a world & $1003(80,9 \%)$ \\
\hline Pgta_08 For the feeling of well-being to know that I can develop nationally and internationally. & $955(77,0 \%)$ \\
\hline Pgta_15 I'm sure that I can contribute to the development of companies. & $919(74,1 \%)$ \\
\hline Pgta_03 Because it will help me to fulfil myself as a specialized person and professional. & $908(73,2 \%)$ \\
\hline Pgta_27 For the satisfaction of knowing that every day I can overcome myself. & $901(72,6 \%)$ \\
\hline Pgta_18 For the pleasure of learning about export and import. & $882(71,1 \%)$ \\
\hline Pgta_25 For the pleasure of learning different things and in a different way. & $881(71,0 \%)$ \\
\hline Pgta_20 For the satisfaction I feel when trying to stand out in what I do. & $875(70,5 \%)$ \\
\hline Pgta_11 For the pleasure of acquiring new knowledge, skills and experiences. & $868(69,9 \%$ \\
\hline Pgta_24 Because it is a good investment for my future because of the wide labor market. & $857(69,1 \%)$ \\
\hline Pgta_23 To be recognized in the international area. & $844(68,0 \%)$ \\
\hline Pgta_19 Because I want to show myself that I can lead in the global economy. & $841(67,8 \%)$ \\
\hline Pgta_04 Because I like to discover interesting things. & $827(66,6 \%)$ \\
\hline Pgta_13 For the pleasure of doing international business. & $814(65,6 \%)$ \\
\hline Pgta_06 For the satisfaction of knowing more and more about business. & $801(64,5 \%)$ \\
\hline Pgta_09 Because I want to give a more positive image to my family and friends. & $693(55,8 \%)$ \\
\hline Pgta_01 To feel good demonstrating my skills. & $667(53,8 \%)$ \\
\hline Pgta_22 Because I know that I will be taught by specialists in international business. & $632(50,9 \%)$ \\
\hline Pgta_12 Because if I don't study, I would feel that I'm missing a great opportunity. & $584(47,1 \%)$ \\
\hline Pgta_26 Because I would feel bad if I didn't. & $366(29,5 \%)$ \\
\hline Pgta_02 Because I don't want to disappoint some people. & $257(20,7 \%)$ \\
\hline Pgta_05 Because I would feel guilty if I didn't study this career. & $215(17,3 \%)$ \\
\hline Pgta_14 I don't care about studying international business or another career. & $207(16,7 \%)$ \\
\hline Pgta_21 I don't know why I chose this career. & $190(15,3 \%)$ \\
\hline Pgta_07 Because I didn't know what to choose. & $156(12,6 \%)$ \\
\hline Pgta_28 I don't care, I just want to finish the career & $125(10,1 \%)$ \\
\hline
\end{tabular}

Note: The frequencies and percentages shown reflect the sum of the categories: quite, very much and totally according to each statement.

When the answers were divided according to the type of university, differences were found in the factors shown in Table 3. 
Table 3. Most important motivations to study international business career according to the type of university in which students belong

\begin{tabular}{|c|c|c|c|c|}
\hline Question & $\mathrm{UC}$ & $\begin{array}{c}\text { Lima } \\
\text { national }\end{array}$ & $\begin{array}{c}\text { Lima } \\
\text { private }\end{array}$ & P Value \\
\hline Because I don't want to disappoint some people. & $12 \%$ & $19 \%$ & $25 \%$ & $<0,001$ \\
\hline $\begin{array}{c}\text { Because I want to give a positive image to my family and } \\
\text { friends. }\end{array}$ & $42 \%$ & $53 \%$ & $62 \%$ & $<0,001$ \\
\hline $\begin{array}{c}\text { For the pleasure of acquiring new knowledge, skills and } \\
\text { experiences. }\end{array}$ & $80 \%$ & $72 \%$ & $66 \%$ & 0,001 \\
\hline For the satisfaction I feel in trying to stand out in what I do. & $62 \%$ & $68 \%$ & $74 \%$ & 0,002 \\
\hline $\begin{array}{l}\text { For the feeling of well-being knowing that I will be able to } \\
\text { develop nationally and internationally. }\end{array}$ & $68 \%$ & $78 \%$ & $79 \%$ & 0,004 \\
\hline Because I didn't know what to choose. & $11 \%$ & $17 \%$ & $10 \%$ & 0,005 \\
\hline For the satisfaction of knowing more and more about business. & $72 \%$ & $59 \%$ & $66 \%$ & 0,006 \\
\hline $\begin{array}{l}\text { Because I am sure that I can contribute to the development of } \\
\text { companies. }\end{array}$ & $69 \%$ & $71 \%$ & $78 \%$ & 0,007 \\
\hline $\begin{array}{c}\text { Because if I don't study, I would feel that I am missing a great } \\
\text { opportunity. }\end{array}$ & $45 \%$ & $42 \%$ & $51 \%$ & 0,009 \\
\hline $\begin{array}{c}\text { To demonstrate to others that I am capable of generating } \\
\text { business opportunities in a globalized world. }\end{array}$ & $82 \%$ & $76 \%$ & $84 \%$ & 0,010 \\
\hline $\begin{array}{l}\text { For the pleasure of learning different things and in different } \\
\text { ways. }\end{array}$ & $74 \%$ & $66 \%$ & $74 \%$ & 0,010 \\
\hline To achieve my goals. & $83 \%$ & $80 \%$ & $87 \%$ & 0,013 \\
\hline I don't care, I just want to finish the career. & $11 \%$ & $12 \%$ & $8 \%$ & 0,085 \\
\hline $\begin{array}{l}\text { Because it will help me to fulfil myself as a specialized person } \\
\text { and professional. }\end{array}$ & $69 \%$ & $71 \%$ & $76 \%$ & 0,093 \\
\hline Because I would feel guilty if I didn't study this career. & $23 \%$ & $17 \%$ & $16 \%$ & 0,100 \\
\hline $\begin{array}{c}\text { Because it is a good investment for my future because of the } \\
\text { wide labour market. }\end{array}$ & $65 \%$ & $68 \%$ & $71 \%$ & 0,137 \\
\hline Because I like to discover interesting things. & $73 \%$ & $66 \%$ & $65 \%$ & 0,152 \\
\hline For the pleasure of doing international business. & $71 \%$ & $63 \%$ & $66 \%$ & 0,155 \\
\hline For the pleasure of learning about export and import. & $77 \%$ & $71 \%$ & $70 \%$ & 0,181 \\
\hline $\begin{array}{l}\text { For the satisfaction of knowing that every day I can surpass } \\
\text { myself. }\end{array}$ & $75 \%$ & $71 \%$ & $74 \%$ & 0,331 \\
\hline To feel good demonstrating my skills. & $59 \%$ & $53 \%$ & $53 \%$ & 0,338 \\
\hline $\begin{array}{c}\text { Because I know that I will be taught specialists in international } \\
\text { business. }\end{array}$ & $55 \%$ & $51 \%$ & $49 \%$ & 0,374 \\
\hline Because I would feel bad if I didn't. & $28 \%$ & $28 \%$ & $31 \%$ & 0,381 \\
\hline I don't know why I chose this career. & $17 \%$ & $16 \%$ & $14 \%$ & 0,456 \\
\hline $\begin{array}{l}\text { Because it is in line with my dreams (travelling, getting to } \\
\text { know new cultures, learning new languages). }\end{array}$ & $84 \%$ & $84 \%$ & $82 \%$ & 0,590 \\
\hline $\begin{array}{c}\text { Because I want to show myself that I can lead in the global } \\
\text { economy. }\end{array}$ & $69 \%$ & $66 \%$ & $69 \%$ & 0,697 \\
\hline To be recognized in the international area. & $66 \%$ & $68 \%$ & $69 \%$ & 0,774 \\
\hline $\begin{array}{l}\text { I don't care about studying international business or another } \\
\text { career. }\end{array}$ & $17 \%$ & $17 \%$ & $17 \%$ & 0,992 \\
\hline
\end{tabular}

Note: The percentages shown reflect the sum of the categories: quite, very much and totally in accordance with each statement. P values were obtained with the chi-square test. 


\subsection{Correlational Result}

For the correlational hypothesis test, the Partial Least Squares (PLS) technique was used for structural equation models (SEM) using SmartPLS software (v. 3.2.8)

\subsubsection{Assessment of the Measurement Model}

Table 4 shows the measurement analysis of the model, based on the reliability and validity of the measurement scales. Regarding reliability, internal consistency of the scales is evidenced through the value of Cronbach Alpha (between 0.720 to 0.861 ) and of the composite reliability (between 0.797 to 0.915 ). With respect to convergent validity, all factor loads are above 0.700. Likewise, all scales have percentages of average variance extracted (AVE) greater than $50 \%$. The discriminant validity of the construct was tested by the criteria of Fornell Larcker, which verifies the independence of each of the scales, considering that the square root of the AVE is greater than the correlations with the rest of the scales. In all cases, the assumption was fulfilled.

Table 4. Results of the model measurement analysis

\begin{tabular}{cccccc}
\hline Variables & $\begin{array}{c}\text { Cronbach } \\
\text { alpha }\end{array}$ & $\begin{array}{c}\text { Composite } \\
\text { reliability }\end{array}$ & $\begin{array}{c}\text { Factor loads } \\
\text { (range) }\end{array}$ & $\begin{array}{c}\text { Average variance } \\
\text { extracted (AVE) }\end{array}$ & $\begin{array}{c}\text { Discriminant } \\
\text { Validity }\end{array}$ \\
\hline AM & 0.720 & 0.839 & $0.726-0.838$ & 0.635 & 0.797 \\
EMer & 0.861 & 0.917 & $0.760-0.946$ & 0.788 & 0.887 \\
EMi & 0.829 & 0.898 & $0.852-0.880$ & 0.754 & 0.863 \\
EMir & 0.734 & 0.848 & $0.775-0.849$ & 0.651 & 0.807 \\
IMa & 0.803 & 0.881 & $0.817-0.885$ & 0.713 & 0.844 \\
IMk & 0.821 & 0.892 & $0.818-0.905$ & 0.734 & 0.857 \\
IMse & 0.775 & 0.868 & $0.770-0.871$ & 0.687 & 0.829 \\
SCIB & 0.805 & 0.911 & $0.903-0.926$ & 0.837 & 0.915
\end{tabular}

As shown in Figure 2, an R2 of 0.510 was obtained, which determines a value greater than 0.100 , which is very significant, showing that $51.00 \%$ of the variance of the SCIB variable is explained by the model.

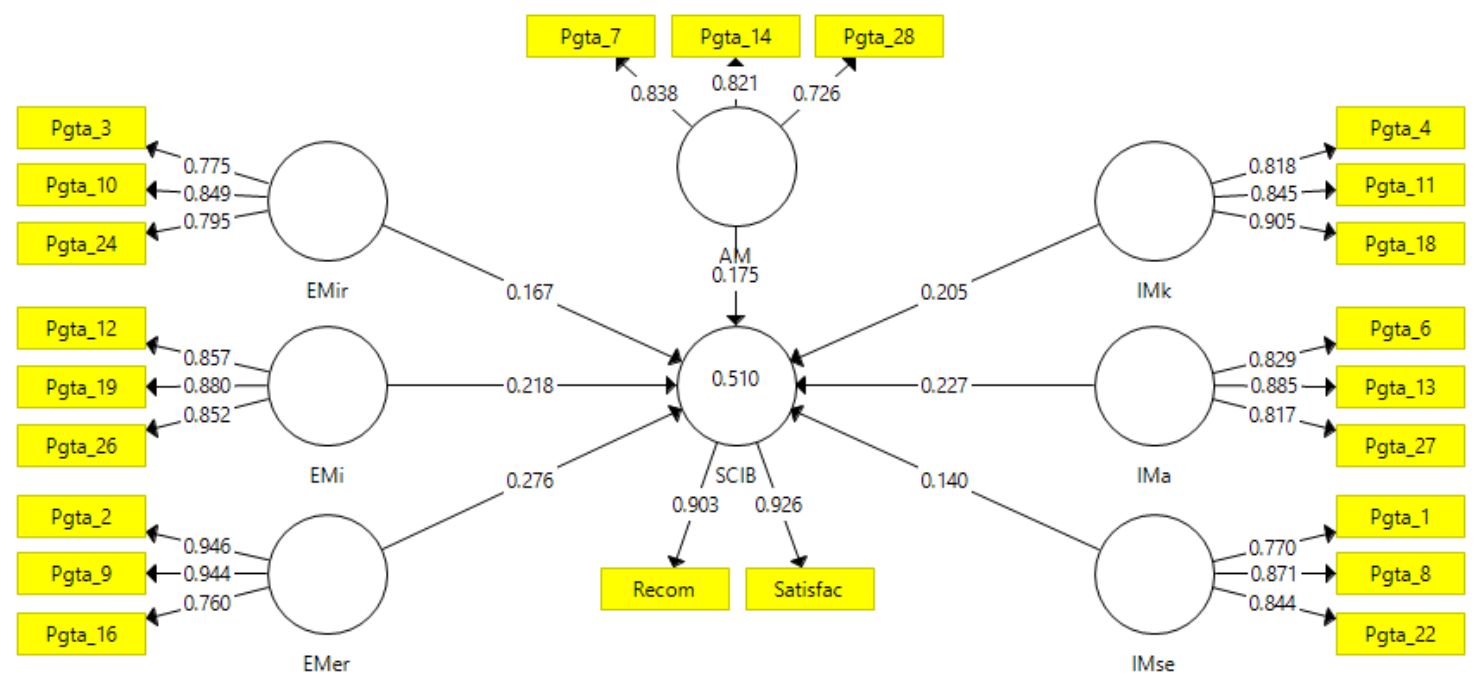

Figure 2. Results for the hypothetized model with structural equations

\subsubsection{Assessment of the Structural Model}

After checking the validity and reliability of the measurement model, the relationships of the constructs were tested. The hypotheses were tested by examining the road coefficients and their levels of significance. Bootstrapping was performed with 5000 sub-samples to check the statistical significance of each of the road coefficients. Figure 3 shows the estimated trajectory of the PLS analysis. 


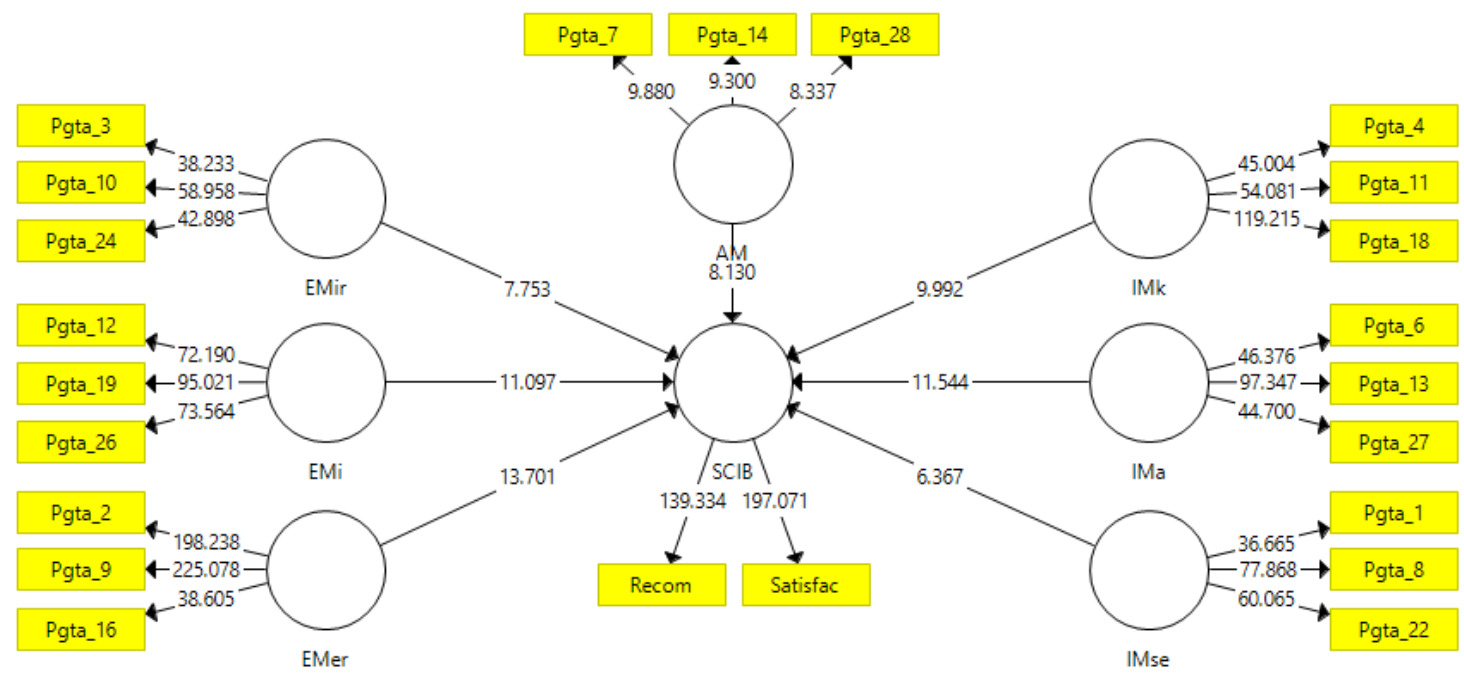

Figure 3. Modeling of academic motivation on the choice of international business career

Considering that the specific relationships have $\mathrm{p}<0.05$, all the hypotheses proposed are accepted as shown in Table 5.

Table 5. Results of the model structure analysis

\begin{tabular}{cccccc}
\hline Hypotheses & Mean sample & $\begin{array}{c}\text { Standard } \\
\text { deviation }\end{array}$ & Beta & p value & Decision \\
\hline AM -> SCIB & 0.175 & 0.175 & 8.130 & 0.000 & Accept H1 \\
EMer -> SCIB & 0.276 & 0.175 & 13.701 & 0.000 & Accept H2 \\
EMi -> SCIB & 0.218 & 0.218 & 11.097 & 0.000 & Accept H3 \\
EMir -> SCIB & 0.167 & 0.167 & 7.753 & 0.000 & Accept H4 \\
IMa -> SCIB & 0.227 & 0.227 & 11.544 & 0.000 & Accept H5 \\
IMk -> SCIB & 0.206 & 0.206 & 9.992 & 0.000 & Accept H6 \\
IMse -> SCIB & 0.140 & 0.140 & 6.367 & 0.000 & Accept H7 \\
\hline
\end{tabular}

\section{Discussion and Conclusion}

Pineda Barón (2015),in the scientific article "Factores que afectan la elección de carrera. Caso Bogota", explains that career choice in general terms is influenced by parents, prior preparation and other characteristics in particular, while in the international business students of the main universities of Peru, it shows that these aspects had an equitable influence on the career choice, since 56\% chose the career because they want to give a more positive image to their relatives and friends, likewise, $17 \%$ because they don't want to disappoint some people.

Polanco Ana (2005), in the article "La motivación en los estudiantes universitarios" of the University of Costa Rica, mentions that motivations are divided into extrinsic and intrinsic, and that these are the ones that causes the interest to make the choice of a career. Ana Polanco showed as a result that there are students who decide for a career that doesn't satisfy them on a personal level, but that the social and family pressure induced them to this choice, while the same is not observed in international business students, since the factors of social and family pressure obtained a low percentage (less than $21 \%$ ).

Cano Celestino (2008), in the article "Motivación y elección de carrera" in the city of San Luis de Potosí in Mexico, has the objective to discover the existence of a relationship between motivation and the choice of the career of Tourism and International Business, obtains as a result that most students chose the professional career by social prestige and economic position, similar to the international business students of the main universities of Peru, these aspects had a great influence on their career choice, as most students chose the career to demonstrate to others what they are capable of doing and achieving, to obtain social and economic prestige. 
Likewise, Troncozo, Garay and Sanhueza (2016) in the article "Percepción de las motivaciones en el ingreso a una carrera del área de la salud", have the objective to identify the motivations that students have when they start studying a career in the health area in the Faculty of Medicine of the Catholic University of the Holy Conception Chile. Obtaining as a result that students are motivated by altruistic aspirations and the vocation of public service, since, in this way they can contribute to society, however, in international business students of Peru, this is not a predominant factor in the choice of their career, to reach your goals, aligned with your dreams (travel, meet new cultures, learn new languages) to show others that it is capable of generating business opportunities nationally and internationally.

Fatoki (2014) in the article "The determinants of the career choice of international students in South Africa", identifies that the most important determinants of the career choice of international students attending business courses: interest in the course, the prestige of the course, The perspective of well-paid jobs, bright future prospects and the influence of job opportunities, the influence of parents and approved subjects. Therefore, it is concluded that the lesson of the international business career is also motivated by the interest of becoming a specialized person and professional, by the satisfaction of knowing that each one can surpass himself and by the pleasure of learning export and import.

The study has the limitation of the selection bias, since, it isn't possible to extrapolate what is found to the totality of students of the evaluated sites, however, having a large representative sample of multiple varieties it can be said that what was found could resemble to reality. This should be replicated and improved by subsequent research, in which there is more sample, more locations and questions that explain the phenomenon.

It is concluded that the most important motivations were the desire to achieve their goals, the fact that it is aligned with their dreams and wants to demonstrate to others that it is capable of generating business opportunities. On the contrary, the main demotivated ones are the ones who don't care and just want to finish the career, who didn't know what to choose and who doesn't know why they chose that career; showing in all these cases a bad choice of the profession.

It is also concluded that "Academic Motivation Scale" remains a valid instrument to determine the factors of academic motivations based on motivation, extrinsic motivations and intrinsic motivations (Chicaiza-Ayala \& Cragno, 2018). Confirming in this research the positive relationship between the different factors of academic motivation and the choice of the international business career. Where the most significant relationship is that between extrinsic motivation with external regulation and the choice of the international business career, to achieve its objectives, such as giving a more positive image to family and friends. Likewise, the least significant relationship is that between the intrinsic motivation to stimulate experiences and the choice of an international business career.

\section{References}

Bandura, A. (2002). Social foundations of thought and action. In D. F. Marks (Ed.), The health psychology reader (pp. 94-106). London: SAGE Publications Ltd. https://doi.org/10.4135/9781446221129.n6

Blašková, M., Majchrzak-Lepczyk, J., Hriníková, D., \& Blaško, R. (2019). Sustainable Academic Motivation Sustainability, 11(21), 5934. https://doi.org/10.3390/su11215934

Cano Celestino, M. A. (2008). Motivacion y Eleccion de Carrera. México: Revista Mexicana de Orientación Educativa. Available

in http://pepsic.bvsalud.org/scielo.php?script=sci_arttext\&pid=S166575272008000100003\&lng=pt\&nrm=iso

Cayanus, J. L., \& Martin, M. M. (2008). Teacher self-disclosure: Amount, relevance, and negativity. Communication Quarterly, 56(3), 325-341. https://doi.org/10.1080/01463370802241492

Chicaiza-Ayala, W., \& Cragno, A. G. (2018). Motivación en 3 escuelas de medicina de Ecuador. Educación Médica, 19, 98-104. https://doi.org/10.1016/j.edumed.2017.03.031

Deci, E., \& Ryan, R. (1985). Intrinsic motivation and self-determination in human behavior. New York: Plenum Press. https://doi.org/10.1007/978-1-4899-2271-7

Deckers, L. (2018). Motivation: Biological, psychological, and environmental. Routledge. https://doi.org/10.4324/9781315178615

Fatoki, O. (2014). The determinants of the career choice of international students in South Africa. Mediterranean Journal of Social Sciences, 5(23), 668. https://doi.org/10.5901/mjss.2014.v5n23p668

Gonzáles Serra, D. J. (2008). Psicología de la motivación. La Habana: Ciencias Médicas. Available in http://newpsi.bvs-psi.org.br/ebooks2010/en/Acervo_files/PsicologiadelaMotivacion.pdf 
Herrera Clavero, F., Ramírez Salguero, M. I., Roa Venegas, J. M., \& Herrera Ramírez, I. (2004). Tratamiento de las creencias motivacionales en contextos educativos pluriculturales. Revista Iberoamericana de Educación, 34(1), 1-21. https://doi.org/10.35362/rie3412885

Patlins, A. (2017, October). Sustainability and motivation in education process of electrical engineers. In 2017 IEEE 58th International Scientific Conference on Power and Electrical Engineering of Riga Technical University (RTUCON) (pp. 1-6). IEEE. Available in http://toc.proceedings.com/37116webtoc.pdf. https://doi.org/10.1109/RTUCON.2017.8124781

Pineda Barón, L. A. (2015). Factores que afectan la eleccion de carrera: caso Bogotá. Universitas Economicas. Available in https://repository.javeriana.edu.co/handle/10554/18494

Polanco Hernández, A. (2005). La motivación en los estudiantes universitarios. Revista Electrónica Actualidades Investigativas en Educación, 5(2),1-13. Available in: https://www.redalyc.org/articulo.oa?id=447/44750219. https://doi.org/10.15517/aie.v5i2.9157

Ryan, R. M. (1995). Psychological needs and the facilitation of integrative processes. Journal of Personality, 63, 397-427. https://doi.org/10.1111/j.1467-6494.1995.tb00501.x

Ryan, R. M., \& Deci, E. L. (2000). Self-determination theory and the facilitation of intrinsic motivation, social development, and well-being. American psychologist, 55(1), 68. https://doi.org/10.1037/0003-066X.55.1.68

Ryan, R. M., \& Deci, E. L. (2017). Self-determination theory: Basic psychological needs in motivation, development, and wellness. Guilford Press.https://doi.org/10.7202/1041847ar

Troncoso Pantoja, C., Garay Lara, B., \& Sanhueza Muñoz, P. (2016). Percepción de las motivaciones en el ingreso a una carrera del área de la salud. Horizonte Médico (Lima), 16(1), 55-61. Available in: http://www.scielo.org.pe/pdf/hm/v16n1/a08v16n1.pdf. https://doi.org/10.24265/horizmed.2016.v16n1.08

Vallerand, R. J., Pelletier, L. G., Blais, M. R., Briere, N. M., Senecal, C., \& Vallieres, E. F. (1992). The Academic Motivation Scale: A Measure of Intrinsic, Extrinsic, and Amotivation in Education. Educational and Psychological Measurement, 52(4), 1003-1017. https://doi.org/10.1177/0013164492052004025

Wilkesmann, U., Fischer, H., \& Virgillito, A. (2012). Academic Motivation of Students-the German Case. Dortmund: Zentrum für Weiterbildung. Available in: https://core.ac.uk/download/pdf/46911775.pdf

Woolfolk, A. (2010). Educational psychology (11th ed.). Upper Saddle River, NJ: Merrill. ISBN-13: 978-0137144549 